in interest among clinical research workers. Some of this applied and clinical respiratory physiology has been published in journals such as Clinical Science, but much has been published in the United States. There the Journal of Applied Physiology has increased, not only in absolute size but in the proportion of its articles on respiratory physiology, so that the number in March 1966 was a mammoth volume weighing $2.75 \mathrm{lb}$. and having no less than forty-six articles in it on respiratory physiology out of a total of about seventy. Obviously, there is a demand for space to publish articles about applied respiratory physiology.

What are the credentials of the new journal Respiration Physiology? First, it is an international journal in English. Secondly, it seems to aim to bring together the different fields of respiratory physiology from cellular respiration, through comparative respiratory physiology in animals, to applied clinical physiology of man. Unlike the Journal of Applied Physiology it is a speciality journal for respiration physiology-as its name implies.

In the first number of Respiration Physiology there are nine papers of original research including articles on a theoretical analysis of aquatic gas exchange, experimental work on respiration in an elasmobranch fish, chemical control of breathing in rats, on the pressure flow characteristics of isolated dog's lungs, on temperature and respiration on sleep, and articles on human breathing including gaseous diffusion on the airways, the effects of posture on compliance, on chemoreceptor block and on the determination of carbon monoxide transfer-a wide variety within the speciality of respiration by authors from the United States, Britain, Germany and New Zealand. If this journal can maintain the high standard of contents and layout of its first number it should surely succeed.

\section{Information Exchange}

Soviet scientific and technical information specialists have just completed a three-week tour of Britain, visiting institutions and organizations concerned with storage, dissemination and retrieval of scientific and technical information. A similar visit to the Soviet Union was made by a team of British information specialists in May 1963. The tour was organized by the International Scientific Relations Division of the Department of Education and Science in Britain. The nine delegates, led by Mr. N. B. Arutynov, head of the Directorate of Scientific and Technical Information, State Committee for Science and Technology, Moscow, visited twenty government and industrial libraries and research establishments.

\section{Appointments}

Dr. J. B. Adains, director of the Culham Laboratory, has been appointed a full-time member of the United Kingdom Atomic Enorgy Authority for 5 years as from October 1 .

Mr. G. J. BeLL has been appointed director of the Royal Observatory, Hong Kong, in succession to Dr. I. E. M. Watts, who has been appointed to the headquarters of the World Metoorological Organization in Creneva.

Prof. D. J. Finney, professor of statistics in the University of Edinburgh, and Mr. J. K. Steward, head of the Mathematics and Computer Dopartment of Imperial
Chemical Industries, Ltd., have been appointed to the Computer Board. These appointments complete the membership of the board, the establishment of which was announced in the House of Commons on August 3.

Prof. I. S. Zheludev has been appointed deputy director general of the International Atomic Energy Ageney for the Department of Technical Operations, in succession to Prof. G. A. Yagodin.

\section{Announcements}

THE Culham Laboratory of the U.K. Atomic Energy Authority is to be awarded a contract worth roughly $£ 3$ million by the European Space Research Organization (ESRO). The authority will be the principal contractor in the development and construction of the first of the three satellites now included in the ESRO programme. This will be largely concerned with astronomical work. The intention is to launch a 30-in. Cassegrain telescope working in conjunction with a spectroscope working in the ultra-violet between $900 \AA$ and $3300 \AA$. It is hoped that the alignment of the telescope will be accurate to within one-tenth of a second of arc. The entire payload will weigh $500 \mathrm{lb}$. and the entire package will be $10 \mathrm{ft}$. long and $40 \mathrm{in}$. wide. The present plan is that the satellite will be launched in 1971 using the ELDO launcher for getting off the ground.

Four new coastal surveying ships, designed to operate in any part of the world independently for long periods, have been ordered by the British Royal Navy. The new ships, being built by Brooke Marine, Ltd., of Lowestoft, will replace the four converted Bay class frigates which have been in service since 1950 . When they are completed, the Royal Navy's surveying fleet will consist of four ocean survey ships, four coastal surver ships and seven smaller boats.

THe Canadian Society for Chemical Engineering has been formed within and as a part of the Chemical Institute of Canada. The new society will represent the institute in the field of chemical engineering, both nationally and internationally. The society's first officers are those of the institute's former Chemical Engineering Division, now replaced by the new society, and are: President, Dr. D. B. Robinson, chairman of the Department of Chemical and Petroleum Engineering in the University of Alberta; Vice-President, Dr. W. H. Gauvin, director of the Noranda Research Centre, Pointe Claire, Quebec; Secretary-Treasurer, Dr. N. E. Cooke, Engineering Department, CIL, Montreal. The new society's first annual meeting will take place during the sixteenth Canadian Chemical Engineering Conference which it is sponsoring in Windsor, Ontario, during October 17-19.

The Harkness Fellowships of the Commonwealth Fund of New York are offered each year for study and travel in the United States. Candidates must be citizens of the United Kingdom or a present British Colony, and must be between the ages of 21 and 32. Further information can be obtained from the Warden, Harkness House, 38 Upper Brook Street, London, W.l.

A JoINT meeting of the Biological Engineering Society and Stichting voor Biofysica will be held at Utrecht during September 22-24. Further information can be obtained from W. J. Perkins, The National Institute for Medical Research, Mill Hill, London, N.W.7.

A Conference on "Advances in Electron Microscopy", arranged by the Electron Microscopy and Analysis Group of the Institute of Physics and the Physical Society and the Electron Microscopy Section of the Royal Microscopical Society, is being held at the Institution of Electrical Engineers during September 26-28. Further information can be obtained from the Meetings Officer, the Institute of Physies and the Physical Society, 47 Belgrave Square, London, S.W.1. 